\title{
THE ALPS: A PHYSICAL GEOGRAPHY, POLITICAL, AND PROGRAM FRAMEWORK
}

Janez Nared, Nika Razpotnik Visković, Blaž Komac

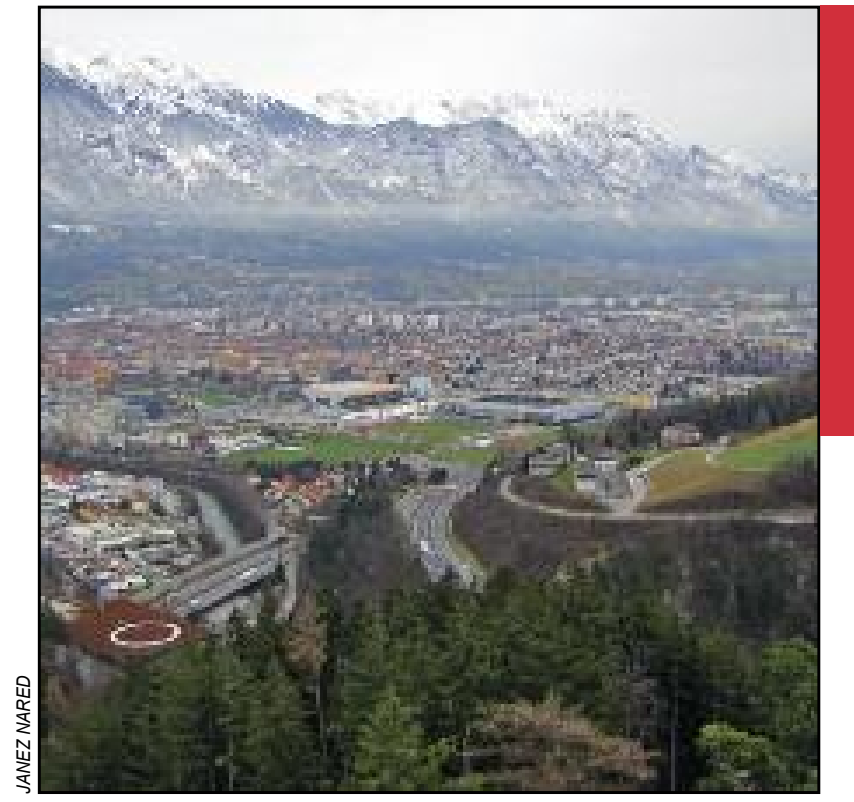

Spatial development is a crucial issue in the Alps, where inhabitants and economic activities are concentrated in Alpine valleys: the case of Innsbruck. 


\section{The Alps: A physical geography, political, and program framework}

DOI: http://dx.doi.org/10.3986/AGS.1970

UDC: $913: 711(234.3)$

$711: 502.131(234.3)$

COBISS: 1.02

\section{ABSTRACT:}

In order to improve the understanding of the concepts featured in this special issue of Acta geographica Slovenica, this review article presents the Alps as a geographical concept, the Alpine Convention, and the Alpine Space transnational cooperation program. All three categories have a different spatial scope and thus must be clearly defined and distinguished from one another.

KEY WORDS: geography, spatial development, sustainability, Alps, Alpine Convention, Alpine Space program

The article was submitted for publication on February $28^{\text {th }}, 2015$.

\section{ADRESSES:}

Janez Nared, Ph.D.

Anton Melik Geographical Institute

Research Center of the Slovenian Academy of Sciences and Arts

Novi trg 2, SI - 1000 Ljubljana, Slovenia

E-mail: janez.nared@zrc-sazu.si

Nika Razpotnik Visković, Ph.D.

Anton Melik Geographical Institute

Research Center of the Slovenian Academy of Sciences and Arts

Novi trg 2, SI - 1000 Ljubljana, Slovenia

E-mail: nika.razpotnik@zrc-sazu.si

Blaž Komac, Ph.D.

Anton Melik Geographical Institute

Research Center of the Slovenian Academy of Sciences and Arts

Novi trg 2, SI - 1000 Ljubljana, Slovenia

E-mail: blaz.komac@zrc-sazu.si 


\section{Introduction}

Due to the vulnerability of the Alps and the interconnection of specific economic, social, and environmental factors in this area, the issue of sustainable spatial development in the Alps has been a concern for experts from all Alpine countries (Cortines, Pecher and Brozzi 2014; Petek 2005; Razpotnik, Urbanc and Nared 2009; Bocco and Zeppetella 2011; Bätzig 2003; Schönthaler, von Andrian-Werburg 2008; Tappeiner et al. 2008; Marzelli, Lintzmeyer and Schwarz 2008; Urbanc, Perko and Petek 2008, Bole and Nared 2010). Because of their rich natural resources, the importance of transport corridors, and exceptional tourism potential, the Alps are exposed to a number of environmental and spatial pressures. The conditions are additionally aggravated by the extremely dynamic terrain, which limits activities and settlement to specific areas. Spatial development is thus torn between the interests of the local population, the business community, environmental protectionists, transport experts, tourism providers, and others that seek opportunities in this attractive mountainous environment.

An analysis of developmental trends at the level of Alpine municipalities (Pfefferkorn 2007) showed that the share of urban municipalities that is, municipalities with high population density, a large number of jobs, and great appeal for workers from neighboring areas has grown considerably over the past decades (it nearly doubled between 1981 and 2001). During the same period, the number of tourism, suburban and peripheral municipalities grew by $41 \%$, whereas the number of balanced and other municipalities decreased by over $60 \%$. Within the EU context, there was an above-average increase in the population and jobs in the Alps, even though despite this growth many workers depend on jobs in major metropolitan regions on the edges of the Alps. In terms of spatial development, the growth in the number of buildings is especially alarming; this increased by a third between 1981 and 2001 . This points to strong suburbanization and urban sprawl, which are especially typical of tourism-oriented municipalities, in which the number of buildings increased by $56.6 \%$. The share of rural population decreased by over $40 \%$ during the same period. These processes indicate great differences in the Alps between the extremely intensive urban and tourism-oriented areas on the one hand and the less promising peri-urban and peripheral areas on the other (Pfefferkorn 2007).

The processes described have significantly transformed the Alps over the past decades and they indicate a need for responsible spatial planning that takes into account the developmental specifics of the Alps and ensures that the Alpine resources and this area's appeal are preserved in the long run, while also ensuring prosperity and a high-quality living environment for the local population.

\section{The Alps: defining the spatial context}

When discussing sustainable spatial development in the Alps, one cannot ignore their spatial context. On the one hand, in terms of physical geography, the Alps are a massif that extends across a good portion of central Europe, and on the other hand, through the adoption of the Alpine Convention and the Alpine Space transnational program, the Alps have also gained a political and developmental connotation. Considering that the physical geographical extent of the Alps differs from that defined in the Alpine Convention and the Alpine Space program, and that familiarity with these areas is important for understanding the articles presented in this special issue, short definitions of these three spatial categories are provided below.

\subsection{The Alps as a mountain range}

The Alps are part of an approximately $1,000 \mathrm{~km}$ long and $250 \mathrm{~km}$ wide mountain chain, which was formed during the Alpine orogeny in the Neogene, approximately sixty-five million years ago. Because they extend across various European regions, they are important for Europe's spatial and sociopolitical development (Diem 2014). Elevated landscapes influenced settlement and routes, and subsequently the frequency and quality of contacts between inhabitants, and the economy (Gams 2001). In order to understand the role of the Alps in spatial development, one must also take into account the neighboring ranges of hills and mountains, such as the Pyrenees, the Apennines, the Massif Central, the Jura Mountains, the Black Forest, the Carpathians, and the Dinarides, and the intermittent lowlands and basins, such as the Po Plain and the Pannonian Basin. 
Janez Nared, Nika Razpotnik Visković, Blaž Komac, The Alps: A physical geography, political, and program framework

The Alps stand in the watershed between the Mediterranean Sea and the north Atlantic, rising from $900 \mathrm{~m}$ at Vienna to almost 5,000 $\mathrm{m}$ in the west, where their highest peak, Mont Blanc $(4,810 \mathrm{~m})$, is located. The Alps have a dynamic terrain, which was transformed significantly by glaciers during the Pleistocene and by hydrogeomorphological processes during the Holocene. Hydrogeomorphological processes continue to have a strong impact on spatial development. In mountainous regions, where heavy rains are frequent, (flash) floods, debris flows, and landslides are common. There are also a lot of rockfalls and avalanches, and earthquakes are common on the southern margins of the Alps.

The Western Alps are the highest, but also the narrowest: on the Italian side the distance between the central ridge and the plain is only about $50 \mathrm{~km}$. In the Central Alps, the valleys and plateaus between them have a different orientation, and the Eastern Alps run in an east-west direction. The central and highest part of the Alps is made of igneous and metamorphic rock, whereas sedimentary rock (especially flysch and limestone) predominates in their northern and southern foothills.

Valleys and basins primarily formed along the faults that run across the Alps and, in addition to the infrequent plateaus and low hills, they are the only areas suitable for settlement. The most important valleys in the Eastern Alps are those extending from east to west (along the Inn and Drava Rivers), and the most important valleys to the west are those that cross the Alps in a north-south direction (Susa, Aosta, Osola and Ticino, Valtellina, Adige) and along which there are around forty major mountain passes (Fedele 2011).

Settlement, thoroughfares, and the economy in the Alps depend on the terrain and the related characteristics of the water resources, climate, and vegetation. The climate is primarily affected by elevation and surface orientation, which is why the Alps are characterized by low summer temperatures and the fact that the temperature amplitude, insolation, heavy rain, and aridity decrease with elevation. The snow line in the Alps lies at 2,500 $\mathrm{m}$ in the central part and at 3,000 $\mathrm{m}$ on the margins, and the receding glaciers are an important source of fresh water (Gabrovec et al. 2014). Alpine rivers are characterized by different seasonal cycles, great discharge fluctuations, and great transport power, which is why the majority of them have formed extensive plains at the foot of the Alps. The southern side of the Central Alps is drained by the Po River, the Rhine flows to the north, the Rhône is the largest river in the west, and the Danube with its tributaries lies in the east. There are several glacial lakes on the edges of the Alps, which are important for tourism. The most important lake in Switzerland is Lake Geneva, and the most popular lakes for tourism are those in Italy (Lake Maggiore, Lake Lugano, Lake Como, and Lake Garda). Others lie to the north: Lake Neuchâtel, Lake Lucerne, Lake Zurich, Lake Constance, Lake Chiem (Chiemsee), and Lake Atter (Attersee). The tourism orientation of the Alps is also highlighted by fourteen national parks, the majority of which are found in Austria and Italy (four each). France has three, and Switzerland, Germany, and Slovenia each have one. In addition to the countries mentioned here, the Alpine countries also include Liechtenstein.

\subsection{The Alpine Convention}

The shared challenges of the Alpine countries and regions, such as spatial planning, transport, the power industry, and tourism, encouraged eight Alpine countries (i.e., Austria, France, Germany, Italy, Liechtenstein, Monaco, Slovenia, and Switzerland) to engage in coordinated international cooperation. In October 1989, ministers from these countries adopted a resolution on preparing a draft treaty governing the protection and sustainable development of the Alps. Based on this, on November 7th, 1991 Austria, France, Germany, Italy, Switzerland, Liechtenstein, and the EU signed the Convention on the Protection of the Alps (Framework Convention 1993; Alpine Convention). Slovenia signed it in March 1993, and Monaco joined it on the basis of a special additional protocol. The Alpine Convention entered into force in March 1995 as the first convention protecting a mountainous region (History 2015).

In terms of organization, the Alpine Convention consists of the following bodies: 1) the Alpine Conference is a political decision-making body composed of the ministers of the member states, of which one assumes the presidency over the convention every two years; 2 ) the Permanent Committee is the executive body of the Alpine Conference composed of representatives of the member states that ensure that the Alpine Convention's ideas, principles, and aims are carried out in practice; another important body of the Alpine

Figure 1: Perimeter of the Alpine Convention (Report on the State of the Alps 2008). 
Acta geographica Slovenica, 55-1, 2015

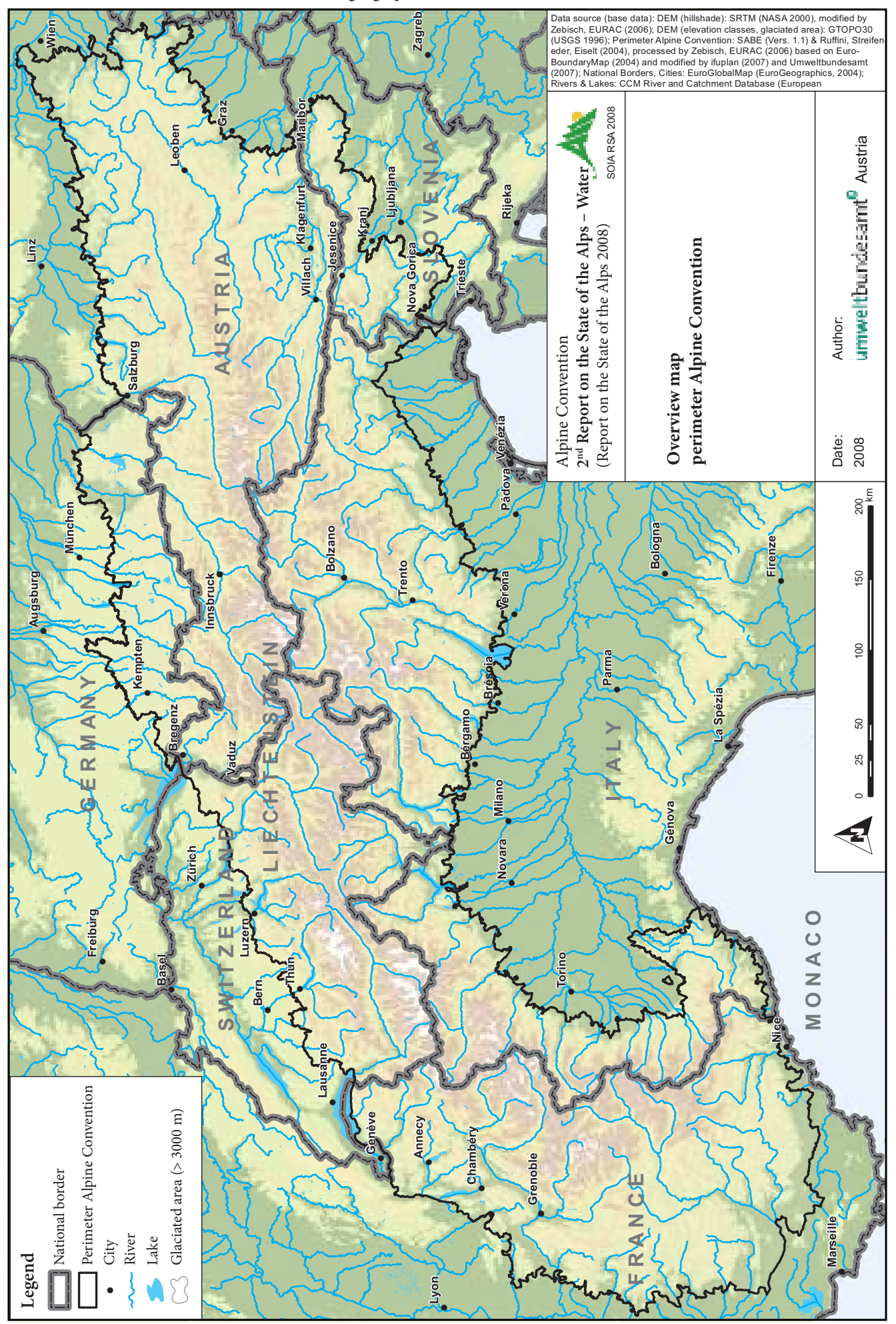


Convention is also 3) the Permanent Secretariat, which supports the bodies established by the convention, provides expert, logistic, and administrative assistance, and helps the member states carry out the activities required by the Alpine Convention and its protocols; other important elements of the convention's organizational structure include 4) the Compliance Committee, 5) the Convention Depository, 6) Working Groups, and 7) Observers (Organization 2015).

In addition to the Framework Convention, protocols and declarations are also important instruments ensuring harmonized spatial development. Protocols provide guidelines in the following areas: spatial planning and sustainable development, conservation of nature and the countryside, mountain farming, mountain forests, tourism, energy, soil conservation, and transport.

Two additional protocols have been adopted: the Protocol on the Solution of Litigations, and the Protocol on the Principality of Monaco's Membership to the Convention. In 2006, two declarations were adopted in addition to these protocols: the Declaration on Population and Culture (2006) and the Declaration on Climate Change (2006).

The joint instruments (i.e., the Framework Convention and its protocols) contribute to the sustainable development of the Alpine region via a uniform development concept, the goal of which is to prevent competition to the detriment of nature and people (The Convention ... 2015). Through this, the Alpine Convention has become a role model for other (mountain) macro-regions around the world, such as the Carpathians and the Andes.

\subsection{The Alpine Space transnational cooperation program}

The Alpine Space transnational cooperation program is carried out as part of the EU cohesion policy. The program connects not only the regions in the geographic macro-region of the Alps (i.e., the mountain chain), but also the surrounding hilly regions and lowlands in the peri-alpine belt, and parts of the Mediterranean coast and the Danube, Po, Adige, Rhône, and Rhine Valleys. Specifically, the program covers the whole of Austria, Liechtenstein, Slovenia, and Switzerland; the Rhône-Alpes, Provence-Alpes-Côte d'Azur, FrancheComté, and Alsace regions in France; Lombardy, Friuli-Venezia Giulia, Veneto, South Tyrol, the Aosta Valley, Piedmont, and Liguria in Italy; and the Freiburg, Upper Bavaria, Swabia, and Tübingen administrative regions in Germany (Internet 1).

The program covers a total area of $450,000 \mathrm{~km}^{2}$, which is home to approximately seventy million people (Internet 2). The region's exceptional diversity is first and foremost the result of the terrain, with mountains forming a physical divide between local communities, which has led to their unique cultural development in the past (Gams 2001). On the other hand, political and economic processes have led to the abandonment of hilly areas, the formation of agglomerations in lowlands, and improved transport accessibility of the Alpine region (Tappeiner, Borsdorf and Tasser 2008). The Alpine Space program brings together regions based on their functional interconnection, which is a necessity for following its basic objectives: directing sustainable spatial development and encouraging spatial cohesion of the entire region, especially by enhancing its competitiveness and attractiveness. The program follows these objectives via projects, in which regions, local communities, and other stakeholders from this area can participate (Strategy Development ... 2013). The essential principle of these projects is the »transnational approach, « which means that they primarily resolve not only local problems and are not limited only to one country, but focus on challenges that demand broader solutions (Internet 2). The project partners from various countries or regions exchange information, knowledge and best practice examples, thus ensuring a higher-quality resolution of problems. The activities within the European territorial cooperation, including the Alpine Space program, are funded by the European Regional Development Fund.

The priorities of the call for project proposals change slightly with each program period. During the 2000-2006 period, the program focused on promoting sustainable development, enhancing accessibility in the Alps, and protecting natural and cultural heritage. During the 2007-2013 program period, the cohesion policy focused on meeting the objectives of the Lisbon and Gothenburg strategies: enhancing economic growth, increasing competitiveness, providing new jobs, and ensuring sustainable and balanced development (Strategy Development ... 2013). These were also the topics of the calls for project proposals within the Alpine Space program. The new program period (i.e., 2014-2020) will continue to promote sustainable development, but the main priorities will include developing an innovative and low-carbon society, sus- 




Figure 2: Regions included in the Alpine Space transnational cooperation program.

tainable use of natural and cultural heritage, conserving and developing the ecological connectivity of Alpine ecosystems, and promoting multilevel governance.

A critical assessment of the results of the Alpine Space program to date show that for now their impact remains intangible and that their implementation in the local environment is insufficient. Therefore, only projects with tangible results in the local environment will be selected and financed in the new 2014-2020 program period (Strategy Development ... 2013, Internet 3).

\section{Conclusion}

According to Onida $(2010,17)$, »the enlarged EU-27 faces considerable new challenges compared to the past years. Challenges increased in number and complexity. This has led to ... new political constructions aimed at facilitating the implementation of EU regional policy objectives and priorities, such as 'regional strategies', in particular in areas where common problems are clearly identified and so are the potential benefits of better coordinated interventions. "What the former Alpine Convention secretary-general had in mind was both the Alpine Convention and the Alpine Space transnational cooperation program, each of which contribute to sustainable development in the Alps in its own way. Shared challenges are an important reason for seeking shared solutions, in which national borders are no obstacle. This is also what this special issue of Acta geographica Slovenica aims to contribute to.

ACKNOWLEDGEMENTS: This article was prepared as part of the project WIKIAlps (a wiki for capitalizing on spatial development projects), co-financed by the Alpine Space transnational cooperation program, which is part of the European territorial cooperation objective of the EU regional policy. 


\section{References}

Bätzing, W. 2003: Die Alpen: Geschichte und Zukunft einer europäischen Kulturlandschaft. München.

Bocco, A., Zeppetella, P. 2011: Innovative policies for Alpine towns: Alpine Space small local urban centres innovative pack. Milano, Torino, Ljubljana.

Bole, D., Nared, J. 2010: Contemporary development issues in the Alps. Regions 280. Seaford.

Cortines, F., Pecher, C., Brozzi, R. (eds.) 2014: WIKIAlps synthesis booklet. Internet: http://www.wikialps-project.eu/ working-material/Documents/WIKIALPS_booklet.pdf (25.2.2015).

Declaration »Population and culture«. 2006. Internet: http://www.alpconv.org/en/convention/protocols/ Documents/PopCult_en.pdf (26.2.2015).

Declaration on climate change. 2006. Internet: http://www.alpconv.org/en/convention/protocols/Documents/ AC_IX_declarationclimatechange_en_fin.pdf (26.2.2015).

Diem, A. 2014: Alps. Encyclopaedia Britannica. London. Internet: http://www.britannica.com/EBchecked/ topic/17356/Alps (3.3.2015).

Fedele, F. G. 2011: Man in the Italian Alps: a study of the Pleistocene and post-glacial evidence. Physical anthropology of European populations. Berlin.

Framework Convention. 1993. Internet: http://www.alpconv.org/en/convention/framework/Documents/ Framework_en.pdf (26.2.2015).

Gabrovec, M., Hrvatin, M., Komac, B., Ortar, J., Pavšek, M., Topole, M., Triglav Čekada, M., Zorn, M. 2014: Triglavski ledenik. Geografija Slovenije 30. Ljubljana.

Gams, I. 2001: O afganistancih in drugih gorjancih. Geografski vestnik 73-1.

History. 2015. Internet: http://www.alpconv.org/en/convention/history/default.html (26.2.2015).

Internet 1: http://www.alpine-space.eu/about-the-programme/asp-2007-2013/cooperation-area (27.2.2015).

Internet 2: http://www.cilj3.mzip.gov.si/index.php?id=25\&lang=sl (27.2.2015).

Internet 3: http://www.alpine-space.eu/fileadmin/media/2014-2020/20140623_ASP_in_a_nutshell.pdf (27.2.2015).

Marzelli, S., Lintzmeyer, F., Schwarz, C. 2008: Managing Alpine land resources - approaches and instruments. Arbeitshefte/Quaderni 51. Bolzano.

Onida, M. 2010: The Alpine Convention as an Instrument for regional policy. Regions 280. DOI: http://dx.doi.org/ $10.1080 / 13673882.2010 .9668764$

Organization. 2015. Internet: http://www.alpconv.org/sl/organization/default.html (26. 2. 2015).

Petek, F. 2005: Tipologija slovenskega alpskega sveta s poudarkom na rabi in spremembah rabe tal. Acta geographica Slovenica 45-1. DOI: http://dx.doi.org/10.3986/AGS45102

Pfefferkorn, W. 2007: Development trends in the Alps. Internet: http://alpsknowhow.cipra.org/main_topics/ development_trends/development_trends_introduction.html (26.2.2015).

Razpotnik, N., Urbanc, M., Nared, J. 2009: Prostorska in razvojna vprašanja Alp. Georitem 12. Ljubljana.

Schönthaler, K., von Andrian-Werburg, S. 2008: Indicators on regional development in the Alps. Arbeitshefte/ Quaderni 49. Bolzano.

Strategy development for the Alpine Space - Final report. 2013. Internet: http://www.alpine-space.eu/fileadmin/ media/Downloads_in_about_the_programme/SDP_Final_Report.pdf (27.2.2015).

Tappeiner, U., Borsdorf, A., Tasser, E. 2008: Alpenatlas. Heidelberg.

Tappeiner, U., Gramm, D., Pecher, C., Tasser, E., Lintzmeyer, F., Marzzeli, S., Tappeiner. G. 2008: Typology of the Alps based on social, economic and environmental aspects. Arbeitshefte/Quaderni 50. Bolzano.

The convention in small bites. 2015. Internet: http://www.alpconv.org/en/convention/Smallbites/thealps/ default.html (26. 2.2015).

Urbanc, M., Perko, D., Petek, F. 2008: Prihodnost Alp in delfi metoda. Geografski vestnik 80-2. 